 \\ JURNAL 2 http://sikola.ppj.unp.ac.id \\ こ \\ JURNAL KAJIAN PENDIDIKAN DAN PEMBELAJARAN \\ ISSN: 2686-3413 (Print) 2715-1735 (Online) \\ DOI: https://doi.org/10.24036/sikola.v1i1.7
}

\section{Efektivitas Institusi Pendidikan dalam Menanggulangi Perilaku Menyimpang Siswa di Era Digital di SMA 4 Kota Payakumbuh}

\author{
Trilorya Elizabeth Sinaga ${ }^{1}$, Reno Fernandes ${ }^{2}$ \\ ${ }^{1,2}$ Universitas Negeri Padang \\ Email: trilorya1996@gmail.com, renofernandes@fis.unp.ac.id.
}

\begin{abstract}
Abstrak
Ide studi ini didasarkan oleh ketertarikan peneliti dalam melihat maraknya perilaku menyimpang siswa pada era digital di kalangan pelajar khususnya di sekolah SMA N 4 Kota Payakumbuh. Studi ini bertujuan untuk mengetahui bagaimana pencapaian dari serangkaian institusi pendidikan dalam menanggulangi perilaku menyimpang terhadap siswa di SMA N 4 Kota Payakumbuh. Studi ini dikaji dianalisis dengan teori Kontrol Sosial oleh Travis Hirschi. Pengumpulan data yang dilakukan dengan cara observasi non partisipatif, wawancara mendalam dengan jumlah 10 orang, studi dokumentasi, yang dianalisis dengan menggunakan teknik analisis data dari Miles dan Huberman. Hasil penelitian menunjukkan bahwa pihak sekolah sudah membuat kebijakan-kebijakan yang telah dibuat agar tidak terjadi lagi perilaku menyimpang (1) keberhasilan sekolah dalam mengurangi perilaku menyimpang. (2) Pendidikan Karakter.
\end{abstract}

Kata kunci: Pendidikan Karakter, Perilaku Menyimpang

\begin{abstract}
The idea of this study is based on the interest of researchers in seeing the rise of deviant behavior of students in the digital era among students, especially in the State Hight School 4 Payakumbuh. This study aims to determine how the effectiveness of educational institutions in tackling deviant behavior towards students in public senior hight school 4 Payakumbuh. This study was analyzed by the theory of social control by Travis Hirschi. This Study uses a descriptive qualitative approach, puspose sampling informant selection technique ith a total 10 informants. Data collection is done by means of observation and participatory, indepth interviews, study of documentation that is analyzed using data analysis techniques from Miles and Huberman. The results of the study sho that the school has made policies that have been made so that deviant behavior does not happen again (the succes of the school in reducing deviant (2) chracter education.

Keywords: chracater education, deviant behavior
\end{abstract}

Received: August 5, 2019 Revised: August 8, 2019

Available Online: September 30, 2019 


\section{Pendahuluan}

Pendidikan adalah hal pokok yang menopang kemajuan suatu bangsa. Kemajuan suatu bangsa diukur dari kualitas dan sistem pendidikan yang ada. Tanpa pendidikan, suatu negara akan jauh tertinggal dengan negara lain. (Nadia Muspita Sari, Erianjoni, 2019). Di era digital perkembangan zaman yang semakin maju menuntut kepada kalangan masyarakat untuk memperoleh informasi secara mudah dan cepat diakses secara online. Kemajuan teknologi adalah suatu hal yang tidak dapat di hindari, seiring perkembangan zaman dan kemajuan IPTEK (Ilmu Pengetahuan dan Teknologi) yang akan selalu muncul inovasi-inovasi teknologi juga diciptakan mempermudah aktifitas manusia. Oleh karena itulah peran penting teknologi ini yang membawa perubahan manusia di era digital yang membantu mempermudah aktifitas manusia dalam segela aspek yaitu aspek ekonomi, politik, kebudayaan, seni dan bahkan dalam dunia Pendidikan (Jaman, Yohannes Marryono, 2018). Sebagai contoh teknologi yang berperan adalah telepon pintar atau gadget.

Ada pun dampak positif dari era digital dengan kemajuan teknologi pada dunia internet mempermudah melaksanakan tugas, menambah pengetahuan, menambah teman dikarenakan jejaring sosial cenderung lebih kreatif, tumbuhnya inovasi dalam berbagai orientasi pada teknologi digital yang memudahkan proses dalam pekerjaan, meningkatkan kualitas sumber daya manusia melalui pengembangan dan pemanfaatan teknologi informasi dan komunikasi serta munculnya berbagai sumber belajar seperti perpustakaan online, media pembelajaran online, diskusi online yang menyediakan berbagai barang kebutuhan agar memudahkan mendapatkan informasi (Hardoyono, Fajar, 2017)

Semakin pesatnya teknologi pada era digital ini terdapat sisi positif dan negatif yang ditimbulkan oleh kemajuan IPTEK yang dikarenakan perkembangan IPTEK. Konsekuensi negatif yang jelas yaitu: kurangnya komunikasi langsung, anak terlihat lebih egois, anak-anak cenderung lebih menyukai hal instant dan yang paling berdampak buruk yaitu mengkonsumsi pornografi dan melakukan seks bebas. Ini merupakan pertanggung jawaban khususnya orangtua, guru, masyarakat sekitar bahkan seluruh bangsa Indonesia karena anak merupakan generasi penerus bangsa.

Pada saat ini penggunaan gadget di pakai oleh kalangan anak-anak, remaja hingga dewasa. Dasarnya gadget merupakan ciptaan dari manusia yang bisa dikontrol manusia, malah sebaliknya kebanyakan manusia yang tidak bisa mengontrol diri mereka dari gadget itu sendiri dan mengakibatkan dampak yang tidak baik bagi kehidupan manusia terutama dikalangan pelajar. Bagi para pelajar juga berdampak buruk pada proses pembelajaran, di mana meraka menggunakan gadget tidak sesuai kondisi, misalnya menggunakan gadget saat proses belajarmengajar berlangsung untuk chatingan dengan teman atau pacar serta membuka situs-situs jejaring sosial pada saat belajar (Rustam Aji, 2016)

Pada saat sekarang ini tuntutan dan tantangan institusi pendidikan semakin tinggi. Institusi pendidikan di era ini setidaknya harus mampu menyiapkan anak didiknya yaitu: a) memiliki kekuatan spritual keagamaan yaitu sebagai landasan dan tujuan hidup, b) pengendalian diri cakap dalam memilih, mengambil keputusan dan tanggung jawab, c) kepribadian yaitu menjadi warga negara, global dan warga toleran, d) kecerdasan dalam memilih, beretika, cermat, kreatif, inovatif dan pekerja keras, berakhlak mulia, e) serta keterampilan secara kognitif dan psikomotorik( Setiawan, wawan 2000).

Semakin tingginya tuntutan dan tantangan institusi pendidikan di Indonesia, maka diperlukan upaya institusi pendidikan dalam membentuk karakter peserta didik agar dapat menghadapi era digital. Maka dari itu Kementerian Pendidikan dan Budaya (Kemendikbud) membuat sebuah kurikulum yang disebut dengan Kurikulum 13 yang dikenal sebagai kurikulum yang membentuk karakter atau sering disebut Pendidikan Karakter. Hal ini sesuai dengan UU No 20 Tahun 2003 tentang Sisdiknas sistem pendidikan Nasional Pasal 3 yang menyebutkan bahwa pendidikan nasional berfungsi mengembangkan kemampuan dan membentuk watak serta peradaban bangsa yang bermartabat dalam rangka mencerdaskan kehidupan bangsa. Pendidikan nasional bertujuan untuk mengembangkan potensi siswa agar menjadi manusia yang beriman 
dan bertakwa kepada Tuhan Yang Maha Esa, berakhlak mulia, sehat, berilmu, cakap, kreatif, mandiri dan menjadi warga negara yang bertanggung jawab (Ristekdikti, go.id). Pendidikan karakter bertujuan agar peserta didik sebagai penerus bangsa mempunyai akhlak dan moral yang baik, untuk menciptakan kehidupan berbangsa yang adil, aman dan makmur.

Sekolah merupakan institusi pendidikan yang mana membentuk karakter siswa menjadi lebih baik. Sekolah ialah rumah kedua bagi anak-anak. Sehingga peran sekolah sangat penting dalam membentuk karakter anak khususnya mengajarkan untuk mengangkat dan membanggakan bangsa(Gana Egar Febriyan, 2017).

Selain sekolah sebagai institusi pendidikan yang berperan dalam menyalurkan bakat-bakat, pendidikan juga berfungsi sebagai kontrol sosial yang mana didalam menjalankan fungsinya sekolah juga sebagai lembaga pendidikan harus mampu mengendalikan perilaku peserta didik sebagaimana mestinya. Tempat mendidik anak-anak menjadi lebih baik dikarenakan anak-anak lebih lama menghabiskan waktu disekolah sehingga pendidik juga memperhatikan perilaku siswa agar menjadi lebih baik. Salah satunya diterapkan pendidikan karakter agar membentuk karakter siswa menjadi lebih baik. Pendidikan karakter dalam Kurikulum 2013 dapat di integrasikan dalam pembelajaran pada setiap mata pelajaran yang berkaitan dengan norma atau nilai-nilai pada setiap mata pelajaran (Saleh, Sirajudin, 2016). Karena itu, pembelajaran nilainilai karakter seharusnya tidak kognitif saja, tetapi menyentuh pada internalisasi dan pengalaman nyata dalam kehidupan peserta didik sehari-hari di sekolah maupun di masyarakat.

Namun masih banyak persoalan-persoalan yang terjadi di dunia pendidikan Indonesia khususnya pada kalangan pelajar yang dipengaruhi oleh teknologi digital (gadget). Menurut Sarlito W. Sarwono mencatat banyak kasus seks bebas atau free sex yang dilakukan oleh kalangan pelajar yang telah mengkhawatirkan semua pihak (lembaga pendidikan, orangtua, masyarakat). Berdasarkan data yang diperoleh dari Kementerian bahwa hasil penelitian di empat kota pada tahun 2016 yaitu Jakarta Pusat, Medan, Bandung, dan Surabaya yang menunjukan sebanyak $35,9 \%$ remaja yang punya teman sudah pernah melakukan hubungan seksual sebelum menikah. Bahkan 6,9\% responden telah melakukan hubungan seksual sebelum menikah.

Bahkan bukan kota besar saja yang terjadi perilaku menyimpang namun dikota kecil yaitu Payakumbuh banyak kalangan pelajar khususnya SMA (Sekolah Menengah Atas) yang melanggar dan melakukan perilaku menyimpang. Terdapat Kasus yang dilakukan kalangan pelajar dikutip dari surat berita yaitu adanya 3 orang siswa yang tidak bisa mengikuti Ujian Nasional karena hamil di luar nikah dalam hal ini data yang didapatkan oleh MUI bahwa ada sekitar 200 perempuan yaitu kalangan pelajar yang hamil diluar nikah diduga kalangan pelajar melakukan arisan seks. Dari data yang di dapat oleh peneliti di kantor Satpol PP, banyak kalangan Pelajar SMA (Sekolah Menengah Atas) tertangkap dan tercatat dalam kasus pelanggaran siswa pada tahun 2018 sebanyak 43 orang. Tahun 2019 sebanyak 93 yang diamankan, 31 pelajar SMP (Sekolah Menengah Pertama) dan 52 orang pelajar SMA (Sekolah Menengah Atas). Dalam hasil wawancara peneliti dengan salah satu petugas Satpol PP mengatakan siswa-siswi tertangkap bermacam-macam kasus yaitu berpacaran disaat jam pelajaran, bermain warnet, game online. Dalam hal ini peran orangtua sekaligus sekolah harus lebih memperhatikan perilaku siswa agar tidak merusak masa depan siswa-siswi.

Untuk mendukung peneliti dalam melakukan penelitian ini terdapat penelitian sebelumnya yang mengkaji dan meneliti hal serupa. Berdasarkan penelitian oleh Muhasim yang berjudul "Pengaruh Teknologi Digital Terhadap Motivasi Belajar Peserta Didik" yaitu: pengaruh positif teknologi digital terhadap motivasi belajar peserta didik dengan tetap diarahkan mengantisipasi pengaruh negatif yang ditimbulkan dapat menganggu moral yang menjadi ancaman bagi motivasi belajar peserta didik. Munculnya free sex dan kenakalan anak-anak remaja karena faktor pengaruh teman pergaulan, dan kurangnya kontrol dari keluarga serta diakibatkan oleh perkembangan teknologi modern, khususnya teknologi komunikasi cenderung menyajikan gambar porno dan video porno (Muzaini ,2017).

Penelitian berikutnya oleh Bahrun Ali Murtopo dari Universitas IAINU Kebumen yang berjudul: "Pendidikan di Era Digital" yaitu digital membawa perubahan besar dalam segala hal 
Trilorya Elizabeth Sinaga, Reno Fernandes Efektivitas Institusi Pendidikan Dalam Menanggulangi Perilaku Menyimpang di Era Digital di SMA N 4 Kota Payakumbuh khususnya pada masalah pendidikan yang menuntut keahlian guru dan orangtua untuk menerapkan solusi dari masalah-masalah tersebut dan tidak merusak ahlak dan moral peserta didik.

Berdasarkan penelitian yang relevan tersebut, terdapat persamaan dan perbedaan dengan penelitian yang peneliti lakukan. Persamaannya sama-sama meneliti tentang perilaku siswa pada Era Digitalisasi yang merusak pada karakter peserta didik. Sedangkan perbedaanya dengan penelitian yang relevan dalam penelitian ini mengkaji Efektivitas Institusi Pendidikan Dalam Menanggulangi perilaku Menyimpang Siswa Pada Era Digital di SMA 4 Kota Payakumbuh.

\section{Metode Penelitian}

Penelitian ini menggunakan pendekatan kualitatif dengan tipe deskriptif. (A Muri Yusuf, 2014). Penelitian kualitatif yaitu suatu penelitian yang ditujukan untuk mendeskripsikan dan menganalisis fenomena, peristiwa, aktivitas sosial, sikap, kepercayaan, persepsi, pemikiran orang secara individu maupun kelompok (Sukmadinanta, 2007). Dan menggunakan penelitian kualitatif tipe deskriptif, adalah metode kualitatif untuk mendapatkan data yang mendalam, suatu data yang mengandung makna (Sugiyono ,2013). Bagi penelitian mengenai studi efektivitas institusi pendidikan dalam menanggulangi perilaku menyimpang siswa di era digital di SMA N 4 Kota Payakumbuh.

Subjek penelitian ini adalah Kepala Sekolah, Wakil Bidang Kesiswaan, Guru BK, Guru Mata Pelajaran, Penjaga Sekolah wawancara di lakukan secara mendalam. Pemilihan informan dengan menggunakan teknik-teknik tertentu bertujuan untuk menjaring sebanyak mungkin infomasi, informan yang di dapat sebanyak 13 orang yang dilakukan secara purposive sampling. Penelitian ini dianalisis dengan menggunakan teknik analisis data dari Miles dan Huberman. kegiatan analisis terdiri dari tiga alur kegiatan yang terjadi secara bersamaan, yaitu reduksi data, penyajian data, dan penarikan kesimpulan/verifikasi.

\section{Hasil dan Pembahasan}

Seks ialah kebutuhan naluriah manusia, namun selama ini dianggap tabu untuk dibicarakan. Seks suatu masalah yang tidak pernah putus untuk dibicarakan secara ilmiah maupun hanya sekadar dibuat penyedap dalam suatu perbincangan yang pasti adanya permasalahan dal hal tersebut.

Pendidikan merupakan hal terpenting untuk membangun prestasi yaitu mencerdaskan kehidupan anak bangsa sesuai Undang-Undang No.20 Tahun 2003. Pada saat melakukan wawancara dengan guru yang ada di SMA N 4 Payakumbuh peneliti mengamati bahwa ada beberapa guru yang tidak bersedia memberikan informasi terkait dengan permasalahan dalam penelitian, tetapi juga beberapa guru yang mau memberikan informasi terkait dengan permasalahan penelitian. Berdasarkan pengamatan peneliti bahwa fungsi guru BK yang ada di SMA N 4 Payakumbuh sudah berjalan dengan baik dalam menanggulangi perilaku tersebut, namun permasalahan tidak ditangani langsung oleh guru BK terlebih dahulu melainkan oleh wali kelas atau guru yang mengetahui permasalahan yang dialami oleh siswa tersebut. Sekolah merupakan institusi pendidikan. Di sekolah selain mendapatkan pendidikan secara akademik siswa juga harus mendapatkan didikan agar menjadi perilaku yang baik sesuai dengan tata tertib dan peraturan, nilai dan norma yang berlaku di masyarakat.

Efektivitas menunjuk pada keberhasilan terhadap pencapaian sasaran sehingga efektivitas digambaran sebagai suatu ukuran apakah mengerjakan pekerjaan yang benar dan tepat. Dilihat dari ketepatan waktu maka efektivitas dapat diartikan sebagai tercapainya berbagai macam sasaran yang telah ditentukan sebelumnya, tepat waktunya dengan menggunakan sumbersumber tertentu yang sudah dilokasikan untuk melakukan sebagai kegiatan (Ulber Silalahi,2002). Efektivitas kontrol sosial muncul di sekolah SMA N 4 Payakumbuh sebagai benuk pengendalian atau cara mengontrol siswa dengan tujuan mendapatkan kedispilinan dan perilaku yang baik, kontrol sosial yang ada di sekolah SMA N 4 Payakumbuh karena adanya beberapa siswa yang melanggar peraturan disekolah sehingga melakukan perilaku menyimpang oleh siswa. 
Mengendalikan kedisplinan hal yang tidak mudah dikerjakan. Displin belajar, absen dikelas, model berpakaian, merupakan masalah yang sudah lumrah dalam peraturan disekolah, namun jika sudah melakukan perilaku menyimpang yaitu seksual yang mengakibatkan hamil diluar nkah merupakan pelanggaran yang tidak bisa ditoleransi lagi. Dalam menanggulangi penyalahgunaan teknologi, pihak sekolah melarang membawa handpone kesekolah tetapi masih banyak. Hukuman yang diberikan sekolah seperti penyitaan dan hukuman lainnya diberlakukan keseluruhan peserta didik. Bagi peserta didik yang ketahuan mengakses atau menyimpan konten yang tidak pantas telah disiapkan sanksi tegas dari pihak sekolah.

Peran merupakan yang digunakan untuk menunjuk pada aspek tugas dan fungsi atau posisi kedudukan. Peranan adalah suatu pola tindakan yang dilakukan oleh sebuah lembaga baik secara invidual maupun secara bersama-sama yang dapat menimbukan suatu peristiwa. Guru adalah peranan yang mempunyai kedudukan kunci di dalam keseluruhan proses pendidikan, terutama dalam pendidikan formal. Sekolah adalah dasar, fungsi dan tujuan tentang peranan sekolah mengembangkan pada kemampuan dan membentuk watak serta peradaban bangsa yang bermartabat dalam mencerdaskan kehidupan bangsa dan negara yang mempunyai watak yang baik.

Dalam hasil observasi di SMA N 4 Kota Payakumbuh dan melakukan wawancara mendalam dengan guru dan staff lainnya bahwasanya sekolah sudah melakukan pendidikan karakter dan memperkuat tata tertib sekolah sesuai dengan tata tertib sekolah. Namun dalam upaya tersebut masih terjadi perilaku menyimpang. Jadi bisa dapat disimpulkan pihak sekolah belum maksimal untuk menciptakan karakter siswa, akhlak mulia. Dalam hal ini pihak sekolah sudah menjadi pengendalian sosial yang bernitiberatkan diri terhadap strategi untuk mengatur tingkah laku siswa dan membaanya kepada nilai dan norma yang berlaku yang ada pada lingkungan sekolah serta menjadikannya berguna pada lingkungan masyarakat. Dalam teori kontrol sosial Trischi mengatakan ada 4 proposisi internal yaitu pertama, attachment yaitu sumber kekuatan muncul dari sebuah sosialisasi di dalam kelompok primer sehingga individu tersebut berkomitmen akan patuh pada peraturan tersebut, kedua commitment yang bertanggung jawab terhadap aturan agar memberikan kesadaran jika mengenai masa depanya jika melakukan perilaku menyimpang, ketiga involment mendorong individu untuk berperilaku partisipatif dan terlibat dalam ketentuan-ketentuan dalam hal tata tertib, keempat belive percaya dan patuh terhadap norma-norma sosial agar tertanam kuat dalam diri seseorang. Dalam hal ini bisa di ungkapkan bahwasanya jika suatu sistem saling berkaitan, jika unsur satu tidak baik maka unsur lainnya berpengaruh terhadap sistem (Fernandes, 2017)

Bahwa berbagai bentuk pengingkaran terhadap aturan-aturan sosial adalah akibat dari kegagalan mensosialisasikan individu untuk bertindak konform terhadap aturan dan tata tertib yang telah ada. Penyimpangan bahkan kriminalitas, merupakan sebuah bukti kegagalan kelompok sosial agar tetap tertib, seperti: keluarga, sekolah, Institusi Pendidikan dan kelompok yang dominan lainya. Setiap individu sebenarnya harus berperilaku sesuai dengan norma dan tidak melakukan tindakan meyimpang. Kontrol internal lebih berpengaruh dibandingkan dari kontrol eksternal.

\section{Kesimpulan}

Berdasarkan hasil penelitian yang peneliti lakukan di SMA N 4 Payakumbuh perlu diberikan pendekatan kepada pendidik untuk nengetahui perihal kehidupan seksual dengan katakata yang sepantasnya. Apabila tidak disampaikan dengan takarannya, seharusnya hasilnya harus baik menjadi disalah artikan bagi siswa tersebut da tidak memberikan pembelajaran. Selain proses pembelajaran peran orangtua dan masyarakat lainnya harus di ikut sertakan. Oleh karena itu menjadi panutan dan memberikan pengarahan,mendamping agar menjadi panutan yang baik.

Perkembangan teknologi yang semakin maju dan canggih meniscayakan remaja mendapatkan pengetahuan dari berbagai sumber. Rasa ingin tahu remaja bisa jadi kontra produktif dengan sumber belajar yang tidak ditemukan secara bertanggung jawab. Sekolah 
merupakan salah satu pengendalia sosial dan kontrol soial dikarenakan peserta didik banyak hampir menghabiskan setengah hari, maka dari itu sekolah sangat berperan. Pendidikan hal penting dalam menciptakan cita cita bangsa Indonesia yaitu mencerdaskan kehidupan anak bangsa yang mengembangkan kemampuan dan membentuk watak serta peradaban bangsa yang bermartabat dalam rangka mencerdaskan kehidpuan bangsa agar menjadikan siswa menjadi lebih beriman dan bertakwa kepada Tuhan, berbudi pekerti, sehat, berilmu, cakap, kreatif, mandiri dan membuat warga negara yang bertanggung jawab.

Lembaga pendidikan berperan dalam mengembangkan sifat kepribadian siswa bahwa sekolah merupakan faktor pemasti bagi perkembangan kepribadiannya, secara berpikir, bertabiat baik, maupun cara berperilaku. Tetapi banyak juga siswa yang melanggar perilaku menyimpang mengakibatkan dapat merugikan masa depan siswa sendiri. Dalam hal ini institusi harus berupaya dalam menanggani perilaku menyimpang siswa.

Salah satu upaya sekolah dalam perilaku menyimpang siswa yaitu dengan melakukan pendidikan karakter. Karakter akan terbentuk bila individu melakukan secara berulang-ulang, secara rutin sehingga menjadi suatu kebiasaaan dan bukan menjadi kebiasaan melainkan menjdi karakter. Pendidikan karater bisa dilakukan dalam semua mata pelajaran yang mana setiap mata pelajaran masih berkaitan dengan nilai dan norma lalu dikaitkan dengan kehidupan sehari- hari.

Pada perkembangan teknologi yaitu di era digital peran sekolah sangatlah penting, namun jika peran dari sekolah saja tidak bisa tanpa peran dari keluarga dan pihak lingkungan masyarakat. Keluarga sebagai tempat utama dan pertama membimbing karakter siswa. Guru juga tidak hanya mengajarkan konsep karakter yang baik, tetapi bagaimana mengarahkan peserta didik untuk dapat mengimplementasikanya pada kehidupan sehari-hari.

1. Disarankan kepada guru untuk membina dan memberikan pengetahuan dampak yang terjadi bagi peserta didik jika melakukan perilaku menyimpang dengan membina karakter yang lebih baik.

2. Disarankan kepada orangtua agar lebih mengawasi dan berperan aktif untuk melihat perkembangan perilaku anaknya serta bekerjasama dengan pihak sekolah

3. Disarankan kepada penelti yang berminat untuk melanjutkan penelitian tentang efektivitas institusi dalam menanggulangi perilaku menyimpang siswa.

\section{Daftar Pustaka}

Agus Wibowo. (2013). Pendidikan Karakter Berbasis Sastra Yogyakarta: Pustaka Pelajar

Fajar Hrdoyono. Strategi Pembelajaran Era Digital. Jurnal Pemikiran Alternatif Pendidikan, Vol. 12, No 12017 STAIN Purwokerto

Febriyan, Gana Egar (2017). Peranan Sekolah dalam Menanggulangi Perilaku Menyimpang Siswa di SMA N 13 Kota Magelang). Skripsi.

Fernandes, R. (2018). Adaptasi Sekolah Terhadap Kebijakan Pendidikan Inklusif. Socius, 4(2), 119-125. doi:10.24036/scs.v4i2.16

Dapertemen Pendidikan Nasional. Undang- Undang No 20 Tahun 2003. Jakarta: Depdiknas, 2013

Elly Setyadi dan Usman Kholip. (2011). Pengantar Sosiologi Jakarta: Kencana

Firmansyah. (2015). "Pengaruh Internet Terhadap Mahasiswa (Studi Terhadap Tim Sepak Bola Mon Malem Blang Bintang Aceh Besar)". Skripsi. Banda Aceh, UIN Ar-Raniry

Herdiansyah, Haris. (2014). Metode Penelitian Kualitatif Untuk Ilmu-ilmu sosial, Jakarta: Salemba Humanika

I Befadhol. (2017). "Lembaga Pendidikan Islam Di Indonesia", Jurnal Pendidikan, Vol 06, No.06,

Muzaini. (2014). "Perkembangan Teknologi dan Perilaku Menyimpan dalam Masyarakat Modern". Jurnal Pembangunan Pendidikan, Vol 2, No. 1

Nadia Muspita Sari, Erianjoni, I. S. (2019). PERILAKU SISWA MENGHADAPI UJIAN NASIONAL BERBASIS KOMPUTER DI SMAN 3 KOTA PARIAMAN TAHUN 2018. 
Trilorya Elizabeth Sinaga, Reno Fernandes Efektivitas Institusi Pendidikan Dalam Menanggulangi Perilaku Menyimpang di Era Digital di SMA N 4 Kota Payakumbuh Jurnal Perspektif, 2(1), 1-11. https://doi.org/http://dx.doi.org/10.24036/ppkt/vol2-iss1/58

Nana, Syodih Sukmadinata. (2017). Metode Penelitian Pendidikan, Bandung: PT. Remaja Rosdakarya

Padang Ekspress. Com/2/5/2014 (https://www.infosumbar.net/berita/berita-sumbar/sumbaredan-pelajar-di-50-kota-melakukan-arisan-seks/ di akses pada tanggal 25 Mei 2019, pukul 18.00 WIB

Ristekdikti.go.id,K (2016). UU RI No 20 Thn 2003 Tentang SISDIKNAS.

Soerjono Soekanto. (1998). sosiologi penyimpangan, Jakarta: KENCANA

Sugiyono. (2013). Memahami Penelitian Kualitatif. Bandung: Alfabeta

Sugiyono. (2017). Metode Penelitian Kualitatif, kuantitatif, dan R\&D, Bandung: Alfabeta,2017

Suharshimi, Arikunto. (2006). Prosedur Penelitian Suatu Tindakan Praktik. Jakarta: Rineka Cipta

Suharsimi Arikunto. (2006). Prosedur Penelitian Suatu Pendekatan Praktik, Jakarta: Rineka Cipta

Sulasena. (2013). Perspektif Perilaku Menyimpang Anak REMAJA: Studi Kasus Berbagai Masalah Sosial. Jurnal Vol. 8, No. 1

Topo Santoso dan Eva Achjani Zulva. (2013). Kriminologi, Jakarta: Raja Grafindo Persada

Ulber, Silalahi. (2002). Pemahaman Praktis Azas-azas Manajemen. Bandung: Manda Maju

Ulber Silalahi. (2009). Metode Penelitian Sosial, Bandung: Refika Aditama

Undang - Undang Republik No.20 Tahun 2003 Tentang Sistem Pendidikan Bab I Pasal I No.4

Wawan Setiawan. (2000). Era Digital dan Tantanganya, Jurnal Pendidikan, Bandung: Universitas Pendidikan Indonesia) I.

Yohannes Marryono Jaman. (2018). Dampak Teknologi Dalam Pendidikan, Jurnal Pendidikan dan Kebudayaan Missio, Vol.10, No. 1

Yohannes Marryono Jamun. (2018) Jurnal: “Dampak Teknologi Terhadap Pendidikan”: STKIP Santu Paulus X.

Yusuf, A Muri. 2014. Metode Penelitian Kuantitatif, Kualitatif \& Penelitian Gabungan. Jakarta: Kencana. 